\author{
(i) Seray Olcay Gul ${ }^{1}$ \\ (D) Avsar ARDIC ${ }^{2}$ \\ D Burcu OLGUNSOYLU ${ }^{3}$ \\ Yesim UNAL ${ }^{4}$
}

\section{Posttraumatic Stress Symptoms and Related Variables in Families of Children with Disabilities}

\author{
Abstract
}

\begin{abstract}
The purpose of this study was to examine the effects and relationships of variables related to the children with disabilities and their parents as well as the diagnosis process and informing parents after the diagnosis and variables which might be related to the traumatic stress levels of the parents of children with disabilities on parents' traumatic stress levels. This study which was conducted as relational research included a total of 347 parents of children with disabilities. Data collection forms included personal information form, Traumatic Stress Symptom Scale, and Multidimensional Scale of Perceived Social Support. The results showed that traumatic stress levels of parents of children with physical impairments were higher than other parents, there was a significant relationship between the time passed after the diagnosis and parents' traumatic stress levels; there was significant relationship between the parents' age and parents's traumatic stress levels; parents' traumatic stress levels didn't differ in terms of gender; traumatic stress levels of single parents were higher than married parents.
\end{abstract}

Keywords: Children with disabilities, parents, posttraumatic stress symptoms.

\section{Introduction}

Having a child with disability is a highly stressful condition in which the parents perceive it as a threat to continuity in healthy family life and their child's physical integrity as well as they face several issues which are difficult to cope with, and they might have different traumatic experiences (Ardıç, 2013; Blacher, Neece, \& Packowski, 2005; McCubbin \& Huang, 1989; Uğuz, Toros, İnanç, \& Çolakkadıoğlu, 2004). These issues and traumatic experiences begin with the first moment that parents doubt whether their child has a disability. The first step of these issues is the diagnosis process. There is a two-step diagnosis process in Turkey as medical and educational (Diken, 2008). In Turkey, medical diagnosis related to the disability is made in full- fledged hospitals according to international diagnosis criteria [i.e., International Statistical Classification of Diseases and Related Health Problems (ICD 10), Diagnostic and Statistical Manual of Mental Disorders $4^{\text {th }}$ Edition, Text Revision (DSM-IV-TR) and $5^{\text {th }}$ Edition (DSM V)]. Succeeding medical diagnosis, Guidance and Research Centers (GRC) conduct educational diagnosis and start placement processes (Ministry of $\mathrm{Na}$ tional Education, 2006). Diagnosis process is time consuming, exhausting, and worrisome regarding its consequences. When this process is finalized, and parents learn that their child has a disability, they face several issues such as the difficulty in explaining their child's condition to others, behavioral and health issues of the child related to the disability, the need to see several experts in terms of treatment and education, the efforts to find appropriate educational settings,

\footnotetext{
${ }^{1}$ Ph.D., Assist. Prof., Hacettepe University, Faculty of Education, Department of Special Education, Ankara, TURKEY. e-mail: solcaygul@gmail.com

e-mail: solcaygul@gmail.com
${ }^{2}$ Ph. D., Assist. Ege University, Faculty of Education, Department of Special Education, İzmir, TURKEY. e-mail: avsar.ardic@ege.edu.tr

${ }^{3}$ Ph.D., Student in MD., Baskent University, Pyschological Counseling and Guidance Center, Ankara, TURKEY. e-mail: burcuolgunsoylu@gmail.com

${ }^{4}$ Ph.D., MD., Istanbul Public Health Directorate, Istanbul, TURKEY. e-mail: yesimu@gmail.com
} 
the need for more time, money, and energy, concerns about their child's future, the change in the roles of the family members for the child with disability, relationship deterioration in the marriage, and not being able to participate in social activities both because of time constraints and the reason not being able to spare time for oneself (Bright \& Hayward, 1997; Kaytez, Durualp, \& Kadan, 2015; Laminen, 2008). Due to these issues, parents may show different psychological reactions such as anxiety, stress, depression, hopelessness, and traumatic stress (Blacher et al., 2005; Lovell, Mass, \& Wetherell, 2015; Weiss, 2002).

Traumatic stress emerges from traumatic experiences that are different from the stress caused by daily sources of stress (Ehlers, Mayou, \& Bryant, 1998). In the book of DSM-IV-TR [American Psychiatric Association (APA), 2007], traumatic experiences are defined as experiencing, witnessing, or facing a real death or a death threat, a severe injury or a threat to oneself or somebody else's physical integrity; whereas in DSM-V the term "traumatic" is replaced by "destructive" and adds the statement of recurring or excessive encountering of the unpleasant details of the events (APA, 2013). In the literature, traumatic experiences which can cause traumatic stress are listed as natural disasters, traffic accidents, attacks, suicide, sickness, losing a relative, bankruptcy, being arrested, rape, torture, terrorist attacks, needing a long term care or having a relative in need of long-term care, and having a child with disabilities (Oflaz, 2008; Symon, 2001); and having a child with disability is defined as a situation which increases the possibility of lifelong traumatic events (Blacher et al., 2005). Even though having a child with disability is explained by the researchers as a situation which causes traumatic stress in parents, it has been addressed in a few research studies; it is stated in the literature that the results of the research studies about the psychological reactions of parents to this situation which threatens the lives and environmental adaptation of parents might be adopted for the effects of trauma as well (Caset et al., 2012; Roberts, Koenen, Lyall, Ascherio, \& Weiskopf, 2014).

There are several studies in which psychological reactions of the parents of children with disabilities are examined. In some of these studies, anxiety, stress, depression, and hopelessness levels of parents of children with disabilities are compared to the parents of children with typical development. Whereas in most of the studies; anxiety, stress, depression, and hopelessness levels of the parents of children with disabilities were higher than the parents of children with typical development (Dehkordi, Kakojoibari, Mohtashami, \& Yehtakha, 2011; Gallagher, Phillips, Oliver, \& Carroll, 2008; Guralnick, Hammond, Neville, \& Connor, 2008; Hayes \& Watson, 2013; Hill \& Rose, 2009; Lovell et al., 2015; Şentürk \& Varol-Saraçoğlu, 2013), only a few studies showed there were not significant differences among parents (Maedow-Orlans, 1994; Fışıloğlu \& Fışıloğlu, 1996).

In some of the studies in which psychological reactions of parents of children with disabilities are examined, the researchers tried to identify the variables, which affect the anxiety, stress, depression, and hopelessness levels of parents. In some of the studies variables which affect the psychological reactions of parents about the disabilities of their children were shown to be related to the child (age, gender, diagnosis, and having behavioral problems; e.g., Dumas, Wolf, Fisman, \& Culligon, 1991; Harpin, 2005; Van Steijn, Oerlemans, Van Aken, Buitelaar, \& Rommelse, 2014), in some others those variables were found to be related to the parents (being mother or father, age, income, educational level, perceived social support level, marital satisfaction, and knowledge levels about their child's characteristics; e.g., Blacher \& Baker, 2007; Falk, Norris, \& Quinn, 2014; Gray \& Holden, 1992; Woodgate, Ateah, \& Secco, 2008); and in some studies the variables were related to the diagnosis process itself (interviews with the experts, duration and the speed of the diagnosis process, and getting information about the diagnosis; e.g., Brogan \& Knussen, 2003; Mansell \& Morris, 2004).

Research studies show that the type of the disability is one of the most effective variables on the anxiety, stress, depression, and hopelessness levels that the parents experience due to the disability of their children. In the literature, there are studies comparing the anxiety, stress, depression, and hopelessness levels of parents of children with different disabilities (Çengelci, 2009; Dabroswka \& Pisula, 2010; Dyson, 1997; Gupta, 2007; Hartley, Seltzer, Head \& Abbeduto, 2012; Hayes \& Watson, 2013; Sayın, 1997; Van Steijn et al., 2014; Weiss, 2002; White \& Hastings, 2004). Some of the 
results of the studies show that there are not any differences among the anxiety, stress, and depression levels of parents of children with intellectual disabilities, hearing impairments, or physical impairments (e.g., Albay, Saltık, Molla, \& Şenveli, 1994; Sayın, 1997), some show that stress and depression levels of parents of children with autism spectrum disorders are higher than parents of children with cerebral palsy, Fragile X syndrome, Down syndrome, problem behaviors, and learning impairments (e.g., Blacher \& McIntyre, 2006; Hartley et al., 2012).

Another variable related to the children that is shown in the research studies to be effective on the psychological reactions of parents is the age of the child. The results of the research studies about the child's age are inconsistent. Some of the studies showed that while the child gets older the parents start to get used to their child's condition and anxiety, stress, depression, and hopelessness levels decrease (Nachshen, Woodford, \& Minnes, 2009; Goff et al. (2006); some demonstrated that while the child gets older because of the issues encountered about health and participation in social life; anxiety, stress, depression, and hopelessness levels of parents increase (Irving, Basu, Richmond, Bum, \& Wren, 2008; Phelps, Pinter, Lollar, Medlen, \& Bethell, 2012). However, in some other studies, the effects of the difference between the age of the child which she or he had the diagnosis and his or her current age was examined; while this difference increased anxiety and stress levels of parents also were shown to increase (Friedrich, Wilturner, \& Cohen, 1985; Sabih \& Sajid, 2008). Socio-demographical variables are the most examined variables among other variables that are targeted in the studies. The researchers examined the effects of the parents' gender, age, income, educational level, and marital status on the anxiety, stress, depression, and hopelessness levels about their child's disability; mothers' stress and depression levels were higher than fathers' (e.g., Bahar, Bahar, Savaş, \& Parlar, 2009; White \& Hastings, 2004); while the educational level increased parents' stress levels decreased (e.g., Akandere, Acar, \& Baştuğ, 2009; Yıldırım-Sarı \& Başbakkal, 2010); when the income was higher parents' stress, anxiety, and depression were lower (e.g., Smith, OIiver, \& Innocenti, 2001; Yıldırım-Sarı \& Başbakkal, 2010); mothers who were single or divorced had higher depression symptoms than who were married (Küllü, 2008; Olsson \& Hwang, 2001).

Social support is the most emphasized variable in the literature that is an effective variable on psychological reactions of parents of children with disabilities (Acierno et al., 2007; Falk et al., 2014). The definition of social support is getting love, attention, trust, respect, information, and financial support from the environment (Cohen \& Wills, 1995), studies in which the effects of social support on psychological reactions of parents of children with disabilities were examined showed that having social support decreases stress and the effects of the stress as well (Boyd, 2002; Duvdevany \& Abboud, 2003; Duygun \& Sezgin, 2003; Feldman, Varghese, Ramsay, \& Rajska, 2002; Lamminen, 2008; Örsal, 1998).

In addition to the variables related to the child and the parents in the research studies, the process of deciding whether the child has a disability, in other words, the diagnosis process (duration, results, and the interaction between the expert and the parents, etc.) is also shown to be a stressful event by its very nature. The studies showed that giving insufficient information during the first diagnosis process and the lack of knowledge in the following periods were important stressful sources for parents of children with disabilities (Ardıç, 2013; Cavkaytar \& Diken, 2006; Çetinkaya \& Öz, 2000; Sen \& Yurtsever, 2007; Todis \& Spinger, 1991); parents indicated that giving information in this process was quite helpful (Osborne \& Reed, 2008), and informing parents after the diagnosis decreased anxiety scores (Uyaroğlu \& Bodur, 2009).

Different than these variables examined in the studies, an unlimited number of environmental, genetic, family related, and personal variables might affect the psychological reactions of parents about their child's disability. Therefore, to find the effective variables for every parent is almost impossible. Similarly, psychological reactions of parents about their child's disability might considerably differ. This study was planned considering the points, which stand out in the direction of the literature. These points can be listed as follows; (a) there are studies in which psychological characteristics of parents of children with disabilities such as anxiety, stress, depression, and hopelessness are examined however there is a lim- 
ited number of studies examining the traumatic stress levels of families. (b) There is a need for research findings that holistically show the effects of variables, which stand out from the related studies about both the parents and the children as well as the diagnosis process on traumatic stress levels of parents caused by their child's disability. (c) There is not any study in which data from different disability groups are simultaneously collected. (d) There is a limited number of studies which included the parents of children with visual impairments (Speedwell, Stantont, \& Nischal, 2003; Tröster, 2001) learning disabilities (Karande, Kumbhare, Kulkarni, \& Shah, 2009), and speech and language impairments (Çelebi, 2005; Dyson, 1997). Considering all these reasons, the main purpose of this study was to examine the effects and relationships of variables, which might be related to the traumatic stress levels of the parents of children with disabilities on parents' traumatic stress levels. In the direction of this main purpose answers to the following research questions were sought: (a) Does the type of disability cause a significant difference in the traumatic stress levels of parents? (b) Is there a relationship between the time passed since the diagnosis of the child with the disability and the parents' post-traumatic stress symptoms? (c) Does marital status (i.e., being mother or father) and the educational level make a difference in their traumatic stress levels, is there a relationship between the age, the socioeconomic level, and the traumatic stress level of the parent? (d) Is there a relationship between perceived social support of parents and traumatic stress levels? (e) Does whether being informed during the diagnosis process or not make a difference in the traumatic stress levels of the parents?

\section{Method}

\section{Research Design}

This study was planned to identify the variables related to the traumatic stress levels of parents of children with disabilities after the diagnosis process and examine the relationship between these variables and the traumatic stress levels. Therefore, this study was a relational research. Relational research is the research in which the relationships between two or more variables are examined without intervening with these variables (Büyüköztürk, Kılıç-Çakmak, Akgün, Karadeniz, \& Demirel, 2017)

\section{Population and Sample}

The population of this study was the parents of children with disabilities who were attending the private special education center to evaluate the children and third researcher worked in this center. Two criteria were used to identify the sample to be chosen from this population. Firstly, children with disabilities must have been diagnosed by both a hospital and a GRC and their parents applied to the private special education center for educational assessment. According to this criterion, from 6 different geographical regions of Turkey, in total from 7 cities (Ankara, Denizli, İstanbul, İzmir, Karabük, Kırıkkale, and Manisa) 430 parents were reached. However, some parents refused to participate in the research. Data from 347 parents who accepted to participate in the study were analyzed. Table 1 includes the distribution and percentages of the participants in each city.

The second criterion to identify the sample was the type of disability. Children who had one of the seven disabilities that are included in special education and support services in Turkey were included in the sample. The children were chosen according to their medical and educational reports; on the basis of "Disability Medical Board Reports" and "Guidance and Research Center Reports," parents were contacted. The sample size of this study included 347 parents who were reached and met these criteria. The response rate is $81 \%$. Children of these parents had either intellectual disability $(n=54)$, autism spectrum disorder $(n=51)$, learning disability $(n=57)$, physical impairment $(n=43)$, visual impairment $(n=51)$, hearing impairment $(n=45)$, or speech and language disorder $(n=46)$. Socio-demographic characteristics of the parents included in this study are listed in Table 2. 
Table 1.

Distribution and Percentages of the Participants in Each City

\begin{tabular}{|c|c|c|c|c|}
\hline \multirow[b]{2}{*}{ City } & \multicolumn{2}{|c|}{ Gender } & \multirow[b]{2}{*}{$\mathbf{N}$} & \multirow[b]{2}{*}{$\%$} \\
\hline & Female (n) & Male (n) & & \\
\hline Ankara & 201 & 48 & 249 & 71.8 \\
\hline Denizli & 1 & 7 & 8 & 2.3 \\
\hline İstanbul & 8 & 1 & 9 & 2.6 \\
\hline İzmir & 37 & 12 & 49 & 14.1 \\
\hline Karabük & 1 & 5 & 6 & 1.7 \\
\hline Kırıkkale & 13 & 4 & 17 & 4.9 \\
\hline Kahramanmaraş & 4 & 5 & 9 & 2.6 \\
\hline Total & 269 & 78 & 347 & 100 \\
\hline
\end{tabular}

Table 2.

Socio-demographical Characteristics of the Participants

\begin{tabular}{llllllllll}
\hline & & & & & \multicolumn{5}{c}{ Educational Level } \\
\cline { 7 - 9 } Gender & $\mathbf{n}$ & $\%$ & $\overline{\mathbf{X}}$ & SD & $\begin{array}{l}\text { Elementary } \\
\text { School }\end{array}$ & $\begin{array}{l}\text { High } \\
\text { School }\end{array}$ & University & Other & Total \\
Female & 269 & 77.5 & 37.76 & 7.97 & 101 & 98 & 69 & 9 & 269 \\
Male & 78 & 22.5 & 42.11 & 6.93 & 20 & 33 & 24 & 2 & 78 \\
Total & 347 & 100 & 38.72 & 7.95 & 121 & 131 & 84 & 11 & 347 \\
\hline
\end{tabular}

\section{Data Collection Tools}

In this study, data was collected by the Personal Information Form, TSSS, and MSPSS.

Personal Information Form: All participants completed Personal Information Form that was developed by the researchers, and it had two parts. On the first part of the form, questions related to the demographical characteristics of parents' age, gender, job, marital status, socioeconomic status and etc. were listed under the title of "information related to the parents", on the second part under the title of "information related to the child" questions related to the demographical characteristics of the child with the disability, diagnosis, and the diagnosis process were listed so that the information related to these variables were collected.

Traumatic Stress Symptom Scale (TSSS): Başoğlu et al. (2001) developed this scale in Turkey, it is a self-assessment scale which has 23 items. TSSS have two subscale which are post-traumatic stress disorders scale and depression scale. However, the total score of TSSS was obtained. Cronbach's Alpha coefficient of all the items in the scale is .94, for post-traumatic stress disorder which has 17 items, Cronbach's Alpha coefficient is .92 and for depression which has six items, Cronbach's Alpha is .84. The sensitivity and specificity of the post-traumatic stress disorder are $81 \%$ (Başoğlu et al., 2001). Internal consistency coefficient of TSSS is examined by calculating Cronbach's Alpha coefficient, and this coefficient is .97 $(\mathrm{N}=347)$. TSSS is a likert type scale and each item is scored from 0 to 3. The total score of TSSS is obtained by calculating the sum of the item scores. In TSSS, the score of 25 and above indicates the sign of post-traumatic stress and depression (Başoğlu et al., 2001).

In the current study, for the parents included in the sample, the internal consistency of TSSS was examined by calculating Cronbach's Alpha coefficient. Results of the analysis showed that for the total 
scores of TSSS Cronbach's Alpha coefficient was .97. Cronbach's Alpha coefficient for post-traumatic stress disorder subscale .95 and for depression subscale is .90 .

\section{Multidimensional Scale of Perceived Social} Support (MSPSS): This scale consists of 12 items and it is developed by Zimet et al. (1988) to evaluate the perceived social support level of the individual from his or her family, friends, and significant other. MSPSS is a likert type scale and each item is scored from 1 to 7 . The lowest score that can be taken from the scale is 12 and the highest score is 84 . The high score obtained from the scale indicates that the perceived support is also high (Zimet et al., 1988).

Validity and reliability studies of the scale for Turkey were conducted by Eker and Arkar (1995); Eker, Arkar, and Yaldız reconducted the factor structure, validity, and reliability studies in 2001. In the subsequent study, data was collected from three different sample groups (individuals with psychiatric disorders, individuals who had a surgeon, and typical individuals), they examined internal consistency of the scale by calculating the Cronbach's Alpha coefficient. Cronbach's Alpha of all items of the scale for all groups is .89 , for MSPSS family subscale it is .85 , for MSPSS friend subscale it is .85, for MSPSS significantother $_{\text {subscale it is }}$ .88 , and for MSPSS subscale it is .92. In the validity and reliability study for parents of children with ASD, Meral and Cavkaytar (2012) found that there was a positive relationship between MSPSS and Family Support Scale total and subscale scores ( $p$ $<.01$ ), Cronbach's Alpha reliability coefficients in this sample for the total scale and its subscales were high $\left(\right.$ MSPSS $_{\text {total }}=.91$, MSPSS family $=.90$, MSPSS friend $=.91$, MSPSS $_{\text {significantother }}=.89$ ), and correlation coefficient for split-half reliability was .92 .

In the current study, for the parents included in the sample, the internal consistency of MSPSS was examined by calculating Cronbach's Alpha coefficient. Results of the analysis showed that for the total scores of MSPSS alpha coefficient was .84, for MSPSS family it was .92 , for MSPSS friend it was .93, for MSPSS significantother it was .60 (N $=347$ ). Cronbach's Alpha coefficient of all the items in the MSPSS were in the acceptable range. Therefore, the scale was accepted as reliable.
In this study, a form was prepared that included all three data collection tools (Personal Information Form, TSSS, and MSPSS) and a consent form. Data was collected by the researchers $(73.7 \%)$ and the principal of the center $(25.3 \%)$ by giving the forms directly to the parents. The forms were filled by the parents and when necessary the researchers helped the parents in filling the forms. The parents completed the form in about 15 to 20 minutes. Data was collected from August to November 2015. Data was statistically analyzed and reported in the following section.

\section{RESULTS}

In total 347 parents of children with seven different disabilities participated in this study. Data was analyzed by SPSS package program and the results are reported in order of the research questions. In the following sections, these results are reported.

The first question of this study was whether there was a difference in the traumatic stress levels of parents regarding the type of the disability. On Table 3, descriptive statistics (number of participants, means, standard deviations, and ranges) of total scores of parents on TSSS regarding the type of the disability are listed. When the table is examined, it can be seen that the highest mean score belonged to the parents of children with physical impairment $(\bar{X}=41.51)$, whereas the lowest mean score was of parents of children with speech and language disorders $(\overline{\mathrm{X}}=17.39)$. Means of parents of children with other disabilities were close to each other. When standard deviations were examined, it was seen that the highest standard deviation was calculated for the parents of children with speech and language disorders $(\mathrm{sd}=20.80)$ and the lowest was for parents of children with intellectual disabilities ( $s d=13.29)$. 
Table 3.

Percentages, Means, Standard Deviations, and Ranges of Parents on the TSSS Regarding the Type of the Disability

\begin{tabular}{llllll}
\hline Type of the Disability & $\mathbf{n}$ & $\%$ & $\overline{\mathbf{x}}$ & SD & Range \\
\hline Intellectual Disability & 54 & 15.6 & 24.85 & 13.29 & 64 \\
$\begin{array}{l}\text { Autism Spectrum Disor- } \\
\text { der }\end{array}$ & 51 & 14.7 & 25.76 & 18.03 & 91 \\
$\begin{array}{l}\text { Learning Disability } \\
\text { Physical Impairment }\end{array}$ & 57 & 16.4 & 22.02 & 16.10 & 69 \\
$\begin{array}{l}\text { Visual Impairment } \\
\text { Hearing Impairment }\end{array}$ & 51 & 12.4 & 41.51 & 20.48 & 70 \\
$\begin{array}{l}\text { Speech and Language } \\
\text { Disorder }\end{array}$ & 46 & 14.7 & 23.86 & 14.74 & 58 \\
\hline Total & 347 & 13.0 & 23.71 & 14.00 & 54 \\
\hline
\end{tabular}

TSSS data was tested by Shapiro-Wilks test and the distributions were not normal data and then distribution of data gathered from TSSS was not transformed into normal distribution by using the data transformation formulas. Therefore, Kruskal-Wallis H test was used to compare the traumatic stress levels of parents regarding the type of the disability of their children. Results of the analysis showed that the traumatic stress levels of parents differed regarding the type of the disability of children $\left(\chi_{(6,340)}^{2}=44.89, \mathrm{p}<.01\right)$. Table 4 includes the results of Kruskal-Wallis $\mathrm{H}$ test.

Table 4.

Kruskal-Wallis H Test's Results of Parents' TSSS Scores Regarding the Type of the Disability

\begin{tabular}{llllll}
\hline Type of the Disability & $\boldsymbol{n}$ & Mean Rank & $\boldsymbol{d f}$ & $\boldsymbol{X}^{2}$ & $\boldsymbol{p}$ \\
\hline Intellectual Disability & 54 & 179.97 & & & \\
Autism Spectrum Disorder & 51 & 177.18 & & & \\
Learning Disability & 57 & 156.38 & & & \\
Physical Impairment & 43 & 254.00 & 6 & 44.89 & .000 \\
Visual Impairment & 51 & 173.50 & & & \\
Hearing Impairment & 45 & 169.01 & & & \\
Speech and Language Disorder & 46 & 115.96 & & & \\
\hline Total & 347 & & & & \\
\hline
\end{tabular}

After Kruskal-Wallis $\mathrm{H}$ test, the data was analyzed by pairwise comparisons was conducted to find the reason for this difference in the traumatic stress levels of the parents regarding the type of the disability. Pairwise comparisons results showed that traumatic stress levels of parents of children with physical impairment $(\bar{X}=41.51)$ differed from traumatic stress levels regarding other types of disabilities. In other words, traumatic stress levels of parents of children with physical impairment are more negative than parents of children with other disabilities and this difference is statistically significant.

The second research question was whether there was a relationship between the time has passed since diagnosis and the traumatic stress levels of parents. The mean for the time passed since the diagnosis is 7.30 years and standard deviation is 6.19 $(\mathrm{N}=300)$. Both variables were tested by Shapiro-Wilks test and the distributions were not normal. Therefore, the relationship 
between the time passed since the diagnosis and scores taken from the TSSS was examined by calculating Spearman rank-order correlation coefficient, and there was a positive and a significant relationship between these two variables $\left(r_{s}=.12, p<.05\right)$.

The third question was whether the marital status, being mother or father, and the educational level made a difference in parents' traumatic stress levels and whether there was a relationship between the age, the socioeconomic level, and the traumatic stress levels of the parents.
The effects of the gender, marital status, and educational level on the traumatic stress levels of parents were individually examined. Firstly, the normality of the variances of the comparison groups by the gender was tested by Shapiro-Wilks test and the distributions were not normal. Therefore, Mann Whitney $U$ test was conducted to examine whether the gender made a significant difference in traumatic stress levels. Table 5 includes the results of the Mann Whitney $U$ test, it shows that there was not a significant difference in the traumatic stress levels regarding the gender $(\mathrm{U}=10442.5, \mathrm{p}>.05)$.

Table 5.

Mann Whitney U Scores of TSSS Scores Regarding Gender of the Parents

\begin{tabular}{llllll}
\hline Gender & $\mathbf{n}$ & Mean Rank & Sum of Rank & $\mathbf{U}$ & $\mathbf{p}$ \\
\hline Female & 269 & 174.18 & 13523.5 & 10442.5 & .95 \\
Male & 78 & 173.38 & 46854.5 & & \\
\hline
\end{tabular}

Whether the post-traumatic stress symptoms significantly differed regarding marital status was examined by Mann Whitney $U$ test and before conducting the analysis whether the variances of the two groups were normally distributed was examined by Shapiro-Wilks test, and the results of the analysis showed that the variances were not normally distributed. Table 6 includes the results of the analysis; it shows that the marital status of the parents significantly affected traumatic stress levels of the parents $(U=5337.5, p<.05)$. Traumatic stress levels of single parents $(\bar{X}=31.17)$ were higher than the married parents $(\bar{X}=24.41)$.

Table 6.

Mann Whitney U Test Results of Parents Regarding Marital Status on TSSS

\begin{tabular}{llllll}
\hline Marital Status & $\mathbf{n}$ & Mean Ranked & Sum of Rank & $\mathbf{U}$ & $\mathbf{p}$ \\
\hline Married & 301 & 168.73 & 50788.5 & 5337.5 & .01 \\
Single & 46 & 208.47 & 9589.5 & & \\
\hline
\end{tabular}

Whether traumatic stress levels of parents differed regarding their educational level was examined by Kruskal Wallis $\mathrm{H}$ test because data was not normally distributed was examined by Shapiro-Wilks test. However, participants who had a degree other than being graduates of elementary and high schools or universities were very few $(n=11)$, so they were added participants who had a degree of universities.
Therefore, Kruskal Wallis $\mathrm{H}$ test was conducted with 347 parents who were graduates of elementary school $(n=121)$, high school $(n=131)$, and university/college $(n=95)$. Table 7 includes the results of the analysis and it shows that the traumatic stress levels of parents regarding their educational level did not significantly differ from each other. In other words, parents' educational level did not change their post-traumatic stress levels.

Table 7.

Results of Kruskal Wallis H Test on TSSS for Parents Regarding Educational Level 


\begin{tabular}{llllll}
\hline Educational Level & $\mathbf{n}$ & $\begin{array}{l}\text { Mean } \\
\text { Rank }\end{array}$ & $\mathbf{d f}$ & $\mathbf{X}^{2}$ & $\mathbf{p}$ \\
\hline Elementary School & 121 & 181.19 & 2 & 1.048 & .59 \\
High School & 131 & 168.41 & & & \\
University & 95 & 172.55 & & & \\
\hline
\end{tabular}

Whether there was a relationship between the age of the parents $(\bar{X}=38.72, s d=7.95$, $\mathrm{N}=345)$, income $(\overline{\mathrm{X}}=2795.42$, $\mathrm{sd}=2054.42$, $\mathrm{N}=319$ ) and traumatic stress levels, Spearman rank-order correlation was conducted because both variables were tested by Shapiro-Wilks test and the distributions were not normal. There was a significant positive relationship between the age of the parent and the TSSS scores $\left(r_{s}=.12, p>.05\right)$, and there was a significant negative relationship between income level and TSSS scores $\left(r_{s}=-.12, p<.05\right)$. This correlation coefficient explained very small part of the variance of parents' TSSS scores so analysis for prediction was not further conducted.

The fourth question of this study was to examine whether there was a significant relationship between the perceived social support of parents of children with disabilities and the traumatic stress levels. For this purpose, the relationship between the total scores of parents on MSPSS ( $\bar{X}=63.23$, $\mathrm{sd}=18.78, \mathrm{~N}=347$ ) and
TSSS was analyzed by Spearman rank-order correlation. The results of the analysis yielded that there was a significant negative correlation between the perceived social support of the parents and their traumatic stress levels $\left(r_{s}=-.25, p<.01\right)$.

The last research question was whether giving information/explanation after the diagnosis would affect parents' traumatic stress levels. Before comparing the scores of parents who were informed and not informed after the diagnosis on TSSS by independent samples t-test, the normality of the distributions was examined by ShapiroWilks test and the data was not normally distributed. Therefore, the data analyzed by Mann Whitney $U$ test. The results of the analysis showed that the scores on TSSS of parents who were informed and not informed after the diagnosis did not significantly differ $(\mathrm{U}=9299, \mathrm{p}>$.05). Table 8 shows the results of the analysis.

Table 8.

Mann Whitney U Test Results of the Parents on TSSS Regarding Being Informed/Explained after the Diagnosis

\begin{tabular}{llllll}
\hline $\begin{array}{l}\text { Being } \\
\text { Informed/Explained }\end{array}$ & $\mathbf{n}$ & Mean Rank & $\begin{array}{l}\text { Sum } \\
\text { Rank }\end{array}$ & of $\mathbf{U}$ & $\mathbf{p}$ \\
\hline Yes & 226 & 163.04 & 37009 & 9299 & .21 \\
No & 89 & 148.82 & 13394 & & \\
\hline
\end{tabular}

\section{DISCUSSION}

In this study, traumatic stress levels of parents of children with different disabilities were examined. Traumatic stress levels of parents differed in terms of type of the disability, while the difference between the time of the diagnosis and the current age of the child increased traumatic stress levels of parents increased as well, traumatic stress levels of parents did not differ in terms of gender and educational level, there was a positive relationship between the age and traumatic stress levels of parents, while the income level and perceived social support increased traumatic stress level decreased, single parents' traumatic stress levels were higher than married parents', there was not a difference in the traumatic stress levels of the parents who 
were informed at the time that the diagnosis was given and who were not informed at that time. Because there were not any studies in the literature about the traumatic stress levels of parents of children with disabilities, the discussion section was based on the studies in which psychological characteristics of parents of children with disabilities such as anxiety, stress, depression, and hopelessness were examined.

In this study, traumatic stress levels of parents of children with physical impairment were significantly higher than the parents of children with intellectual disability, hearing impairment, visual impairment, learning disability, ASD, and speech and language disorder. The reason for this might be because children with physical impairment might continue to be dependent on their parents in different degrees throughout their lives and they might encounter more issues in the environments in which they spend their lives. In the literature, it is emphasized in some studies that the anxiety, stress, depression, and hopelessness levels of parents of children with different disabilities change in terms of type of the disability (Dabrowska \& Pisula, 2010; Hayes \& Watson, 2013; van Steijn et al., 2014; Weiss, 2002), however in some other studies, it is concluded that there is not a significant difference in the anxiety, stress, depression, and hopelessness levels of parents of children with different disabilities (Albay et al., 1994; KuloğluAksaz, 1990; Sayın, 1997). In this regard, the results of this study both support and differ from the findings in the literature.

In this study, there was a strong positive correlation between the traumatic stress levels of parents and the time passed since the diagnosis was given to their child. This might be due to the fact that firstly while the time passed parents might have needed more for meeting the needs of their children regarding care, education, and health, and so forth; secondly they might have started to recognize that their child's condition was not temporary; as well as it might be due to that to different degrees the children with disabilities need their parents' care throughout their lives, and the parents might worry what would happen to their children in the future in their absence or when they pass away (Beavers, Hampson, Hulgus, \& Beavers, 1986; Dönmez, Bayhan, \& Artan, 2000). It is also indicated in the literature that for the following reasons parents' anxiety, stress, depression, and hopelessness levels increase: while the age of the children with disabilities increase their supervision becomes difficult and child's difference from their peers starts to grab more attention of others, the child faces different developmental difficulties during the transition times, and she or he cannot achieve the behaviors of her or his age (Calderon \& Greenberg, 1999; Friedrich et al., 1985; Hollahan, 2003). Additionally, studies conducted with the parents of children with disabilities show that there is an increase in the stress levels while the age of the child increases (Friedrich et al., 1985; Sabih \& Sajid, 2008). Different than these results in the literature, Nachshen et al. (2003) and Goff et al. (2016) found that while the children grew older, parents started to get used to the disability process and their stress levels decreased as well.

The results of this study showed that traumatic stress levels of parents did not differ regarding their gender and educational level and there was a significant positive relationship between the age and the traumatic stress level of parents. This finding of the research revealed that there is a positive relationship between the time since the children were diagnosed and the parents' traumatic stress levels. This result is consistent with a positive relationship between parents' age and traumatic stress levels; the research findings show that the parents' age does not affect the stress level of the parents (Yıldırım-Sarı \& Başbakkal, 2010). Traumatic stress levels of parents differed regarding the marital status and income level, parents' scores on TSSS only explained the 1-2\% of the variance, in other words, explained very small part of it. There are several studies in the literature that examined the effects of socioeconomic variables on anxiety, stress, depression, and hopelessness levels of parents of children with disabilities however their results are inconsistent. The results of this study are parallel with the results of some of the previous studies in the literature that showed that anxiety, stress, depression, and hopelessness levels did not change 
in terms of gender and educational level (e.g., Uğuz et al., 2004), however it differes from some of the other studies which showed that these levels changed according to gender and educational level (e.g., Akandere et al., 2009; Falk et al., 2014). In this study, traumatic stress levels of single parents were higher than married parents, and traumatic stress levels of parents with low income were a little higher than the parents with higher income. These results are parallel with the literature (e.g., Küllü, 2008; Olsson, \& Hwang, 2001; Smith, Oliver, \& Innocenti, 2001; Yıldııım-Sarı \& Başbakkal, 2010). Single parents take on the responsibility for their child on their own; they strive for different stressors alone; the parents with low income have difficulties in meeting needs of their children in education, care, and health. These might have caused the parents to have more traumatic stress in this study.

There was a significant negative relationship between traumatic stress levels and perceived social support however this relationship explained quite a small part of the variance. Nevertheless, the studies on this topic show that social support is the most significant predictor of stress (Weiss, 2002) and traumatic stress (Gökler, 2007); while the social support enlarges and the satisfaction from the support increases anxiety, stress, and depression levels decrease (Cavkaytar, Batu, \& Çetin, 2008; Falk et al., 2014; Feldman et al., 2002; Guralnick et al., 2008; Lamminen, 2008; Plant \& Sanders, 2007).

In this study, $71.4 \%$ of the families were informed after their children's diagnosis process finished. In the studies in which needs of parents of children with disabilities were examined, it was found that the most important need of the parents was the need to be informed about the disability (Cohen \& Wills, 1985; Jones \& Passey, 2004). The results of this study showed that parents were mostly informed. There was not a significant difference between the traumatic stress levels of parents who were informed or not informed. In the literature not giving information about the diagnosis to the parents and the way of giving the information are shown to be important sources of stress and anxiety (Ardıç, 2013; Cavkaytar \& Diken, 2006; Obsorne \& Reed, 2008; Uyaroğlu \& Bodur,
2009). In this regard, this study is different than previous studies. This result might have been due to the way of giving the information and the reactions of parents such as surprise, shock, denial, and fear and so forth when the diagnosis was given. In total $68.5 \%$ of the parents in this study indicated that a doctor initially informed them. The parents might not have taken sufficient explanatory information about the diagnosis and the characteristics of the diagnosis because of the terminology the doctors used. Similarly, $79.7 \%$ of the parents indicated that they were shocked and frightened when they first learned the diagnosis. Another reason for that might be that parents could not focus on the information because of surprise, shock, and fear.

The results of this study might show that traumatic stress levels of parents are more correlated with other variables or a cluster of variables in interaction with each other and the variance of traumatic stress level might be reexamined regarding other variables.

One of the limitations of this study was that the self-report scales were used to gather information. The limitations that the subjective evaluations of participants in self-report scales can be applied to this study as well. Collecting data by one of the scales, i.e., MSPSS, was thought to create a limitation to collect data for the perceived support of parents from their immediate environment. The majority of the sample consisted of mothers, and there was not a control group in this study. In the following paragraph, based on these limitations and results suggestions for future research and implementations are given.

In future research, data can be collected from parents of children with different diagnosis groups; clinicians can collect data using post-traumatic stress scales. Besides support from the immediate environment, data related to support from organizations, experts and so forth can be gathered and analyzed as well. Moreover, in future research, the effects of variables such as the degree of the disability, whether the child has additional disabilities, whether the child has problem behaviors, and the degree of these problem behaviors on traumatic stress can also be examined. 
For the implementation, it can be suggested to the experts/organizations that give services to the children with disabilities that they could develop and implement individual or group counseling programs for parents of children with disabilities. Additionally, following the diagnosis process, the experts might inform parents about the characteristics of their children, how to nurture their children, and how and from where they could get the services which they need for their children in a way that the parents could understand, and they could regularly give psychological counseling in this process.

\section{REFERENCES}

Acierno, R., Ruggiero, K. J., Galea, S., Resnick, H. S., Koenen, K., Roitzsch, J., et al. (2007). Psychological sequelae resulting from the 2004 Florida hurricanes: Implications for postdisaster intervention. American Journal of Public Health, 97(1), 103108.

Akandere, M., Acar, M., \& Baştuğ, G. (2009). Investigating the hopelessness and life satisfaction levels of the parents with mental disabled child. Selçuk Üniversitesi Sosyal Bilimler Enstitüsü Dergisi, 22, 23-32.

Albay, E., Saltık, S., Molla, S., \& Şenveli, B. (1994). Depression and anxiety in parents of children with mental and/or physical retardation. Trakya Üniversitesi Tıp Fakültesi Dergisi, 11, 62-90.

APA, (2007). Diagnostic and Statistical Manual of Mental Disorders-4th edition: Text Revision. E. Köroğlu (Trans.). Ankara: Hekimler Yayın Birliği.

APA, (2013). Diagnostic and Statistical Manual of Mental Disorders-5th edition. E. Köroğlu (Trans.). Ankara: Hekimler Yayın Birliği.

Ardıç, A. (2013). Effects of psycho-educational group program on the some psychological variables of parents whose the children with autistic spectrum disorders. Doctoral dissertation, Anadolu University, Eskişehir, Turkey.
Bahar, A., Bahar, G., Savaş, H. A., \& Parlar, S. (2009). Identifying depression and anxiety levels and styles of dealing with stress of mothers of children with disabilities. Firat Sağlık Hizmetleri Dergisi, 4(11), 97112.

Başoğlu, M., Şalcıoğlu, E., Livanou, M., Özeren, M., Aker, T., Kılıç, C., \& Mestçioğlu, Ö. (2001). A study of the validity of a screening instrument for traumatic stress in earthquake survivors in Turkey. Journal of Traumatic Stress, 14(3), 491509.

Beavers, J., Hampson, R., Hulgus, Y., \& Beavers, W. (1986). Coping in families with a retarded child. Family Process, 25(3), 365-378.

Blacher, J. \& Baker, B. L. (2007). Positive impact of intellectual disability on families. American Journal on Mental Retardation, 112, 330-48.

Blacher, J., Neece C. L., \& Paczkowski, E. (2005). Families and intellectual disability. Current Opinion in Psychiatry, 18, 507-13.

Blacher, J. \& Mclntyre, L. L. (2006). Syndrome specificity and behavioural disorders in young adults with intellectual disability: Cultural differences in family impact. Journal of Intellectual Disability Research, 50(3), 184-198.

Boyd, B. (2002). Examining the relationship between stress and lack of social support in mothers of children with autism. Focus on Autism and Developmental Disabilities, 17, 208.

Bright, J. \& Hayward, P. (1997). Stigma and mental illness: A review and critique. Journal of Mental Health, 6, $345-354$

Brogan, C. A. \& Knussen, C. (2003). The disclosure of a diagnosis of an autism spectrum disorder: Determinantsof satisfaction in a sample of Scottish parents. Autism, 7(1), 3146.

Büyüköztürk, Ş., Kılıç-Çakmak, E., Akgün, Ö., Karadeniz, S.., \& Demirel, F. (2017). Bilimsel Araştırma Yöntemleri. Ankara: Pegem Akademi.

Calderon, R. \& Greenberg, M. (1999). Stress and coping in hearing mothers of children with hearing loss: 
Factors affecting mother and child adjustment. American Annals of the Deaf, 144(1), 7-18.

Casey, L. B., Zanksas, S., Meindl, J.N., Parra, G. R., Cogdal, P., Powell, K. (2012). Parental symptoms of posttraumatic stress following a child's diagnosis of autism spectrum disorder: A pilot study. Research in Autism Spectrum Disorders, 6(3), 1186-1193.

Cavkaytar, A. \& Diken, I., H. (2006). Özel egitime giriş [Introduction to special education]. Ankara: Kök Yayıncılık.

Cavkaytar, A., Batu, S., \& Çetin, O. (2008). Perspectives of Turkish mothers on having a child with developmental disabilities. International Journal of Special Education, 23(2), 101-109.

Çelebi, F. (2005). Determining parental attitudes towards speech and language therapy services. Master's thesis, Anadolu University, Eskişehir, Turkey.

Çengelci, B. (2009). A comparison of level of anxiety, hopelessness and burnout syndrome of mothers who have children with diagnosis of autism or Down syndrome. Ege Eğitim Dergisi, 10(2), 1-22.

Çetinkaya, Z. \& Öz, F. (2000). The effect of providing planned information over the fulfillment of information needs of mothers having children with cerebral palcy. C.U. Hemşirelik Yüksek Okulu Dergisi, 4, 40-51.

Cohen, S. \& Wills, T. A. (1985). Stress, social support and buffering hypothesis. Psychological Bulletin, 98(2), 310- 357.

Coşkun, Y. \& Akkaş, G. (2009). The relation which between anxiety level of the mothers who have disabled children and social support. Ahi Evran University Kırşehir Eğitim Fakültesi Dergisi, 10(1), 213- 227.

Dabroswka, A. \& Pisula, E. (2010). Parenting stress and coping styles in mothers and fathers of pre-school children with autism and Down syndrome. Journal of Intellectual Disability Research, 54(3), 266-80.

Dehkordi, M., Kakojoibari, A., Mohtashami, T., \& Yektakhah, S. (2011). Stress in mothers of hearing im- paired children compared to mothers of normal and other disabled children. Audiol, 20(1), 128-136.

Diken, İ. H. (2008). Otistik bozukluğu olan öğrenciler. İ. H. Diken (Ed.). Özel eğitime gereksinimi olan öğrenciler ve özel eğitim içinde (s. 409-440). Ankara: Pegem Akademi.

Dönmez, B., N., Bayhan, P., \& Artan, İ. (2001). Examining issues encountered by families of children with disabilities in the course of life cycle. Hacettepe Üniversitesi Toplum ve Sosyal Hizmet Dergisi, 12(2), 31 43.

Dumas, J. E., Wolf, L. C., Fisman, S. N., \& Culligan, A. (1991). Parenting stress, child behavior problems, and dysphoria in parents of children with autism, Down syndrome, behavior disorders, and normal development. Exceptionality, 2(2), 97-110.

Duvdevany, I. \& Abboud, S. (2003). Stress, social support and well-being of Arab mothers of children with intellectual disability who are served by welfare services in northern Israel. Journal of Intellectual Disability Research, 47(4-5), 264-272.

Duygun, T. \& Sezgin, N. (2003). The effects of stress symptoms, coping styles and perceived social support on burnout level of mentally handicapped and healthy children's mothers. Türk Psikoloji Dergisi, 18(52), 37-52.

Dyson, L. L. (1997). Fathers and mothers of school-age children with developmental disabilities: Parental stress, family functioning, and social support. American Journal on Mental Retardation, 102(3), 267-279.

Ehlers, A., Mayou, R. A., \& Bryant, B. (1998). Psychological predictors of chronic posttraumatic stress disorder after motor vehicle accidents. Journal of Abnormal Psychology, 107(3), 508-519.

Eker, D. \& Arkar, H. (1995). Çok boyutlu algılanan sosyal destek ölçeğinin faktör yapısı, geçerlik ve güvenirliği [Factorial structure, validity, and reliability of the multidimensional scale of perceived social support]. Türk Psikoloji Dergisi, 34, 45-55. 
Eker, D., Arkar, H., \& Yaldız, H. (2001). Factorial structure, validity, and reliability of revised form of the multidimensional scale of perceived social support. Türk Psikiyatri Dergisi, 12(1), 17-25.

Falk, N. H., Norris, K., \& Quinn, M. G. (2014). The factors predicting stress, anxiety and depression in the parents of children with autism. Journal of Autism and Developmental Disorders, 44, 3185-3203.

Feldman, M., Varghese, J., Ramsay, J., \& Rajska, D. (2002). Relationships between social support, stress and mother-child interactions mothers with intellectual disabilities. Journal of Applied Research in Intellectual Disabilities, 15(4), 314-323.

Fişıloğlu, A. \& Fişıloğlu, H. (1996). Turkish families with deaf and hard of hearing children: A systems approach in assessing family functioning. American Annals of the Deaf, 141, 230-235.

Fiske, K. (2009). A cross-sectional study of patterns of renewed stress among parents of children with autism. Doctoral dissertation, Rutgers University, USA.

Friedrich, W. N., Wilturner, L. T., \& Cohen, D. S. (1985). Coping resources and parenting mentally retarded children. American Journal of Mental Deficiency, 9(2), 130-139.

Gallagher, S., Phillips, A., Oliver, C., \& Carroll, D. (2008). Predictors of psychological morbidity in parents of children with intellectual disabilities. Journal of Pediatry Psychology, 33(10), 1129-1136.

Goff, B. S. N., Monk, J. K., Malone, J., Staats, N., Tanner, A., \& Springer, N. P. (2016). Comparing parents of children with Down syndrome at different life span stages. Journal of Marriage and Family, 78, 11311148.

Gökler, I. (2007). The Turkish adaptation study of social support appraisals scale to be used with children and adolescents: Factor structure, validity and reliability. Çocuk ve Gençlik Ruh Sağlığı Dergisi, 14(2), 90-99.

Gray, D. E. \& Holden, W. J. (1992). Psycho-social well-being among the parents of children with autism. Australia and New Zealand Journal of Developmental Disabilities, 18, 8393.

Gupta, V. B. (2007). Comparison of parenting stress in different developmental disabilities. Journal of Developmental and Physical Disabilities, 19, 417-425.

Guralnick, M., Hammond, M., Neville, B., \& Connor, R. (2008). The relationship between sources and functions of social support and dimensions of child and parent-related stress. Journal of Intellectual Disability Research, 1138-1154.

Harpin, V. A. (2005). The effect of ADHD on the life of an individual, their family, and community from preschool to adult life. Archives of disease in childhood, 90, 12-17.

Hartley, S. L., Seltzer, M. M., Head, L., \& Abbeduto, L. (2012). Psychological well-being in fathers of adolescents and young adults with Down syndrome, fragile $X$ syndrome, and autism. Family Relations, 61, 327-342.

Hayden, M., \& Goldman, J. (1996). Families of adults with mental retardation: Stress levels and need for services. Social Work, 41(6), 657-667.

Hayes, W., \& Watson, S. L. (2013). The impact of parenting stress: A metaanalysis of studies comparing the experience of parenting stress in parents of children with and without autism spectrum disorder. Journal of Autism Developmental Disorder, 43(3), 629-42.

Hill, C., \& Rose, J. (2009). Parenting stress in mothers of adults with an intellectual disability: Parental cognitions in relation to child characteristics and family support. Journal of Intellectual Disability Research, 53, 969-980.

Hollahan, N. C. (2003). Parental coping and family functioning in families with children with mental retardation and chronic illness. Doctoral dissertation, Georgia State University, USA.

Irving, C., Basu, A., Richmond, S., Burn, J., \& Wren, C. (2008). Twenty-year trends in prevalence and survival of Down syndrome. European Journal 
of Human Genetics, 16, 13361340.

Jones, J. \& Passey, J. (2004). Family adaptation, coping and resources: Parents of children with developmental disabilities and behaviour problems. Journal on Developmental Disabilities, 11(1), 31-46.

Karande, S., Kumbhare, N., Kulkarni, M., \& Shah, N. (2009). Anxiety levels in mothers of children with specific learning disability. Journal of Postgraduate Medicine, 55, 165-170.

Kaytez, N., Durualp, E., \& Kadan, G. (2015). Evaluation of requirements and stress levels of the families having a disabled child. Eğitim ve Öğretim Araştırmaları Dergisi, 4(1), 197214.

Kazak, A. (1987). Families with disabled children: Stress and social network in three samples. Journal of Abnormal Child Psychology, 15(1), 137 140.

Kazak, A. E. \& Marvin, R. S. (1984). Differences, difficulties and adaptation: Stress and social networks in families with a handicapped child. National Council on Family Relations, 33(1), 67-77.

Küllü, Z. (2008). Özürlü çocuk sahibi ebeveynlerde depresyon durumunun değerlendirilmesi [Evaluation of depression in parents of children with disabilities]. Yüksek lisans tezi, Erciyes Üniversitesi, Kayseri.

Kuloğlu-Aksaz, N. (1990). Anxiety levels of parents of children with autism and teachable mental retardation. Türk Psikoloji Dergisi, 7 (25), 14- 20.

Lamminen, L. (2008). Family functioning and social support in parents of children with Autism Spectrum Disorders. Doctoral dissertation, University of Kentucky, USA.

Lovell, B., Moss, M., \& Wetherell, M. A. (2015). The psychophysiological and health corollaries of child problem behaviours in caregivers of children with autism and ADHD. Journal of Intellectual Disability Research, 59, 150-157.

Maedow-Orleans, K. (1994). Stress, support, and deafness: Perceptions of infants' mothers and fathers. Journal of Early Intervention, 18, 91-102.
Mansell, W. \& Morris, K. (2004). A survey of parents' reactions to the diagnosis of an autistic spectrum disorder by a local service: Access to information and use of services. Autism, 8(4), 387-407.

McCubbin, M. \& Huang, S. (1989). Family strengths in the care of handicapped children: Targets for intervention. Family Relations, 38(4), 436-443.

Meral, B. F. \& Cavkaytar, A. (2012). A Study on social support perception of parents who have children with autism. International Journal on New Trends in Education and Their Implications, 3(3), 124-135.

Ministery of Education (MEB) (2006). Özel Eğitim Hizmetleri Yönetmeliği. https://orgm.meb.gov.tr/ adresinden 4.10.2016 tarihinde edinildi.

Nachshen, J. S., Woodford, L., \& Minnes, P. (2003). The family stress and coping interview for families of individuals with developmental disabilities: A lifespan perspective on family adjustment. Journal of Intellectual Disability Research, 47, 285290.

Osborne, L. A. \& Reed, P. (2008). Parents' perceptions of communication with professionals during the diagnosis of autism. Autism, 12(3), 309324.

Oflaz, F. (2008). Hasta çocuk ebeveynlerinin pediatrik yoğun bakım deneyimi ve travmatik stres [Pediatric intensive care experience and traumatic stress of ill children and their parents]. Cumhuriyet Üniversitesi HYO Dergisi, 12(1), 53-59.

Olsson, M. B. \& Hwang, C. P. (2001). Depression in mothers and fathers of children with intellectual disability. Journal of Intellectual Disability Research, 45, 535-543.

Örsal, Ö. (1998). Hemşirelik perspektifinden özürlülük [Disability from the perspective of nursing]. Retrieved from http://www.dezavantaj.org/index.php/aratirmalar/8-engelli/289hemsirelik-perspektifinden-ozurluluk-.

Özsoy, S. A., Özkahraman, Ş., \& Çallı, F. (2006). Review of hardships under- 
gone by families with mentally retarded children. Aile ve Toplum Dergisi, 3(9), 69-76.

Phelps, R. A., Pinter, J. D., Lollar, D. J., Medlen, J. G., \& Bethell, C. D. (2012). Health care needs of children with Down syndrome and impact of health system performance on children and their families. Journal of Developmental \& Behavioral Pediatrics, 33, 214-220.

Plant, K. M. \& Sanders, M. R. (2007). Predictors of care-giver stress in families of preschoolaged children with developmental disabilities. Journal of Intellectual Disability Research, 51(2), 109-124.

Roberts, A. L., Koenen, K. C., Lyall, K., Ascherio, A., \& Weisskopf, M. G. (2014). Women's posttraumatic stress symptoms and autism spectrum disorder in their children. Research in Autism Spectrum Disorders, 8(6), 608-616.

Sabih, F. \& Sajid, W. (2008). There is significant stress among parents having children with autism. Rawal Medical Journal, 33(2), 214-216.

Sayın, G. (1997). The relationship between the types of stressors, the causal attributions, the type of disability and the stress levels of the mothers of children with mental disabilities hearing impairment and physical disabilities. Master thesis, Middle East Technical University, Ankara.

Sen, E. \& Yurtsever, S. (2007). Difficulties experienced by families with disabled children. Journal for Specialists in Pediatric Nursing, 12(4), 238-52.

Şentürk, M. \& Varol-Saraçoğlu, G. (2013). A comparison between mothers having healthy children and mothers having physically and mentally handicapped educable children in terms of their perceived familial social support and depression levels. International Journal of Basic \& Clinical Medicine, 1(1), 4049.

Smith, T., Oliver, M., \& Innocenti, M. (2001). Parenting stress in families of children with disabilities. American Journal of Orthopsychiatry, 71(2), 257-261.
Speedwell, L., Stanton, F., \& Nischal, K. (2003). Informing parents of visually impaired children: Who should do it and when? Child Care Health Development, 29(3), 219-224.

Symon, J. B. (2001). Parent education for autism: Issues in providing services at a distance. Journal of Positive Behavior Interventions, 3(3), 160-174.

Todis, B. \& Springer, G. (1991). Stress and stress management in families with adopted children who have severe disabilities. Research and Practices for Persons with Severe Disabilities, 16(1), 3-13.

Tröster, H. (2001). Sources of stress in mothers of young children with visual impairment. Journal of Visual Impairment and Blindness, 95(10), 623-637.

Uğuz, Ş., Toros, F., İnanç, B. Y., \& Çolakkadıoğlu, O. (2004). Zihinsel ve/veya bedensel engelli çocukların annelerinin anksiyete, depresyon ve stres düzeylerinin belirlenmesi. Klinik Psikiyatri, 7, 42-47.

Uyaroğlu, A. \& Bodur, S. (2009). Anxiety of parents of mentally handicapped children and effects of informing on anxiety level. TSK Koruyucu Hekimlik Bülteni, 8(5), 405-412.

Van Steijn, D. J., Oerlemans, M., Van Aken, M. A. G., Buitelaar, J. K., \& Rommelse, N. N. J. (2014). The reciprocal relationship of ASD, ADHD, Depressive symptoms and stress in parents of children with ASD and/or ADHD. Journal of Autism and Developmental Disorders, 44, 10641076.

Weiss, M. J. (2002). Hardiness and social support as predictors of stress in mothers of typical children, children with autism, and children with mental retardation. Autism, 6(1), 115-130.

White, N. \& Hastings, R. (2004). Social and professional support for parents of adolescents with severe intellectual disabilities. Journal of Applied Research in Intellectual Disabilities, 17(3), 181-190 
Woodgate, R. L., Ateah, C., \& Secco, L. (2008). Living in a world of our own: The experience of parents who have a child with autism. Qualitative Health Research, 18, 1075-1083.

Yıldırım-Sarı, H., \& Başbakkal, Z. (2010). Depression among mothers of children and adults with intellectual disability in Turkey. International Journal of Nursing Practice, 16, 248253.
Yılmaz, B. (2006). Posttraumatic stress symptoms and posttraumatic growth in rescue workers. Doctoral dissertation, Ankara University, Ankara, Turkey.

Zimet, G., Dahlem, N., Zimet, S., \& Farley, G. (1988). The multidimensional scale of the perceived social support. Journal of Personality Assessment, 55, 610-617. 